\title{
Corruption in Public Procurement in Ghana: societal norm or deviant behaviour?
}

\author{
Mawuko Dza \\ School of Business, \\ University of Education, Winneba, Ghana \\ Evan Kyeremeh \\ School of Business, \\ University of Education, Winneba, Ghana \\ Simon S. K. Dzandu \\ Koforidua Technical University, \\ Koforidua, Ghana \\ Samuel Affran \\ School of Business, \\ University of Education, Winneba, Ghana
}

\begin{abstract}
The paper probes corruption in public procurement in Ghana. The research, which focused on Metropolitan, Municipal and District Assemblies (MMDAs) across the country, revealed widespread corruption in the public service of Ghana. Notable procurement related corrupt practices unraveled included influence peddling, inflating contract sums, payment for non-existing contracts, deliberate contract splitting, multiple payments for contracts, use of phantom vendors and misapplication of public funds. The study further noted that some principal officers such as Coordinating Directors, Finance Officers, Budget and Planning officers, Engineers, Internal Auditors, Stores and Procurement officers, as well as government representatives misappropriate funds meant for development projects in their catchment areas, while staff looked on unconcerned. The research also discovered how Internal and external auditors ostensibly "train" principal officers on how to conceal corrupt practices in return for money and other rewards. The study is significant because the concept of decentralization was introduced to enable MMDAs to effectively and efficiently manage resources for the development of their communities. The concept has been defeated as some public servants connive with external auditors and other stakeholders to amass wealth at the expense of the generality of the people. A worrying phenomenon is the culture of silence by employees who are witnesses to most of these corrupt practices. Indeed, our findings show that most public servants are nonchalant about the act of corruption perpetuated by colleague workers. Essentially, some employees see nothing wrong with their principal officers and other colleagues indulging in acts of corruption, their reason being that they might do same when they assume similar positions in future. With this revelation, the onus is on government not to only adopt a combative strategy in dealing with the incidence of corruption. Rather, it is recommended that a blend of combative and the moral suasion strategies be adopted if the fight against corruption is to achieve desired results.
\end{abstract}

Keywords: corruption, public service, procurement, moral suasion Ghana.

\section{INTRODUCTION}

Ghana's Public Sector like all others contributes significantly to the growth and development of the country. Generally, the public sector serves as the wheels on which government policies are 
implemented with the objective of bringing development to the doorsteps of citizens. Indeed, because of their role in ensuring socio-economic development across the country, the work of public servants is always under public scrutiny. Regrettably, the public sector of Ghana has been tainted with allegations of corruption, nepotism, conflict of interest, influence peddling, among others. Successive reports of the Auditor General have pointed to widespread procurement related corruption, embezzlement, misappropriation and misapplication of public funds by staff of the service. For instance, the Auditor General's report of 2016 revealed that, stores and procurement irregularities during the period amounted to GH\$35,940,445.43. These irregularities according to the report were mainly as a result of failure on the part of staff to follow procurement procedures prescribed in the Public Procurement Act 2003 (Act 663) as amended. These breaches include; failure to obtain the required numbers of quotations, contract splitting and exceeding authorized thresholds (Auditor-General's Report, Ghana, 2016).

The Public Procurement Act, Act 663 of 2003 as amended was enacted to promote transparency, non-discrimination, equal treatment of all bidders, and the formulation of an institutional framework for managing public procurement activities. However, despite the promulgation of the Act, public procurement in Ghana is fraught with abuse such as the use phantom venders, false claims, and presentation of fictitious invoices for payment. Perhaps what is most worrying is the culture of silence of public servants towards corruption (Stansbury, 2005). This unfortunate development where public servants and sometimes communities look on unconcerned when the state is short changed by public servants is a worrying phenomenon creeping into the Ghanaian society. For instance, through connivance between staff and suppliers, incomplete, and orders not meeting required specifications are accepted, with receiving slips indicating that a full order with the required specifications was delivered. This happens even though the receiving officer is fully aware that the order is incomplete. It is also worthy to note that sometimes inventories in stores are deliberately marked as obsolete or scrap to be discarded, only for staff to either sell or use the items.

Ironically, few decades ago, the issue of corruption was mostly associated with political office holders. For this reason, there was little attention on public servants as far as corruption is concerned. This statement is by no means absolving politicians from procurement related corruption. Indeed, because the Public Procurement Act enjoins the President of the Republic to appoint entity chairpersons in consultation with the Council of State and others, these entity chairpersons who are representatives of the political party in government sometimes compromise the integrity of the bidding, and selection process, considering the fact that the country runs "a winner takes all" kind of politics, where the victor in a political election appoints members of their political parties to occupy almost all political positions irrespective of their levels of experience and competency.

It is a truism that research on corruption in public procurement in Ghana is nothing new; in fact the Auditor General's reports on corruption in the public service show the intensity of the phenomenon. This assertion notwithstanding, research output in the area has mostly concentrated on the criminality aspects of the phenomenon thereby referring to the act of corruption as deviant behaviour. The objective of this paper is to investigate the issue of whether Ghanaians consider corruption as a societal norm and therefore see nothing wrong with the practice or they see it as an act carried out by miscreants in the society. The study hence bridges the knowledge gap of finding out whether corruption is one of the acceptable societal norms of Ghana or if it is an activity carried out by deviants in the Ghanaian society. This invariably contributes to the extant literature by unravelling and putting to the fore the perception of corruption in Ghana. 


\section{PUBLIC PROCUREMENT IN GHANA}

Public Procurement in Ghana is subject to the Public Procurement Act (Act 663) as amended and its implementing regulatory and administrative instructions. The Act and regulations provide the general rules governing Public Procurement in Ghana. The public procurement manual on the otherhand provides guidelines and step-by-step procedures to assist procurement entities to undertake public procurement in accordance with the Act (Public Procurement Manual, 2003). In order to achieve sound anticipated benefits of good procurement practices in Ghana, the Public Procurement Authority (PPA) was constituted to take charge of the Public Procurement Act 2003 (Act 663) as amended, Act 2016 (Act 914). The overall objective of the public procurement system is to provide value for money by ensuring that public funds are spent in a transparent, efficient and fair manner (Public Procurement Manual, 2003). The rationale for enacting the public procurement Act is to correct short-falls in the public financial management system especially in areas of building human resource capacity of practitioners, establishing a uniform institutional framework for public procurement, formulating a public procurement policy, instituting a regulatory and legal framework for public procurement, defining roles and responsibilities of public procurement stakeholders, among others (Public Procurement Manual, 2003)

\section{CORRUPTION IN PUBLIC PROCUREMENT IN GHANA}

Evidence from across the globe confirms that corruption hinders economic development; reduces social services; diverts investments in infrastructure and social services and impacts the poor disproportionately (Khramkin, 2007). Corruption in public procurement comes in different forms, most of which are complementarily used to make it difficult for such corrupt practices to be detected (Ware et al, 2007). According to the OECD report in 2013, public procurement is one of government activities that is most vulnerable to corruption. In addition to the volume of transactions and the financial interests at stake, corruption risks are exacerbated by the complexity of the process - the close interaction between public officials and businesses, and the multitude of stakeholders. Various types of corrupt acts may exploit these vulnerabilities, such as embezzlement, undue influence, bribery of public officials involved in the contract award process, or fraud in bid evaluations, invoices or contract obligations. In many OECD countries, significant corruption risks arise from conflict of interest in decision-making, which may distort the allocation of resources through public procurement (European Commission, 2014a).

The volume and complexity of a particular procurement process play an essential role when it comes to corruption among public servants in Ghana (Auditor-General's Report Ghana, 2016). The larger the procurements, the most vulnerable the corruption, as bribes are frequently demanded by public officials and paid as a percentage of the public contract's value by suppliers. Bartle and Korosec (2003) outlined situations that leave an opening for corruption which include the principal/agent situation, lack of transparency, weak systems, incompetent officials, conflict of interest, seeking justification to bend the rules, multi-jurisdictional corruption, poor accountability arrangements, and weak internal controls. Public officials who receive bribes or accept an undue advantage may return the corrupt favour by restricting or eliminating competition. They may do so by dividing contracts which should be aggregated, tailoring award criteria to a favoured company, approving anti-competitive consortia which would otherwise violate anti-trust laws, accepting non-responsive bids, hosting flawed bid openings or staging discriminatory contract negotiations (UNCAC, 2013). 


\section{CORRUPTION: SOCIETAL NORM OR DEVIANT BEHAVIOUR?}

Research has shown that the social and economic damage of corruption is more pervasive in the public sector than other sectors of economies. Consequently, the incidence of corruption in the public sectors of many economies have generated intense debate among researchers and anti-corruption crusaders as to whether the phenomenon could be considered as a mere deviant behaviour perpetuated by miscreants in society or whether the practice should be likened to acceptable societal norm. In their study on corruption, Csapodi et; al., (2011), found that persistent corrupt behaviour often develops into a social norm as society becomes used to the practice and hence accepts deviant behaviour as the new social norm. For instance, in his research, Mishra (2005) opined that the widespread nature of corruption in societies is an indication that corrupt behaviour has become the acceptable norm among societies. This conclusion is grounded on the premise that, despite the numerous anti-corruption policies put in place by governments the world over with the objective of reducing the incidence of corruption in both the public and private sectors; the phenomenon still persists among people in different societies and cultures (Pertiwi, 2018). Regrettably, a worrying development especially in emerging economies is that corruption is seen as the 'new normal' or an acceptable way of dealing with people. This invariably indicates a high degree of social acceptance of corruption where the practice is seen as "normal" rather than a deviant behaviour (Hoffmann \& Patel 2017). It is therefore significant to assert that corruption is a rather complex social phenomenon, which is deep rooted in countries' socio-cultural, political and traditional systems. For this reason, it would be a mistake to treat corruption only as a deviant behaviour because doing that would make it impossible to reduce the incidence of corruption (Blackburn et; al., 2009). There is therefore a crucial need to rethink the formulation of anti-corruption strategies in order to account for locally prevailing conditions and context-specific drivers of corruption. This calls for the inclusion of hidden agendas, social habits and deeply engrained attitudes towards corruption (Baez-Camargo \& Passas, 2017). Consequently, formulating anti-corruption policies require a thorough understanding of those social beliefs and expectations that have supported the persistence of corrupt practices to begin with. This calls for more nuanced complementary approaches that incorporate a contextualized understanding of behavioural drivers of corruption (Pertiwi, 2018).

\section{CONCEPTUAL FRAMEWORK}

In figure 1 below, the conceptual framework developed based on the review of extant literature is presented. In the framework, the proposed connection between the deviant behaviour and societal norms are the dependent variables whilst corruption in public procurement serves as the independent variable. 
Figure 1: Deviant Behavior, Societal Norm and Corruption in Public Procurement

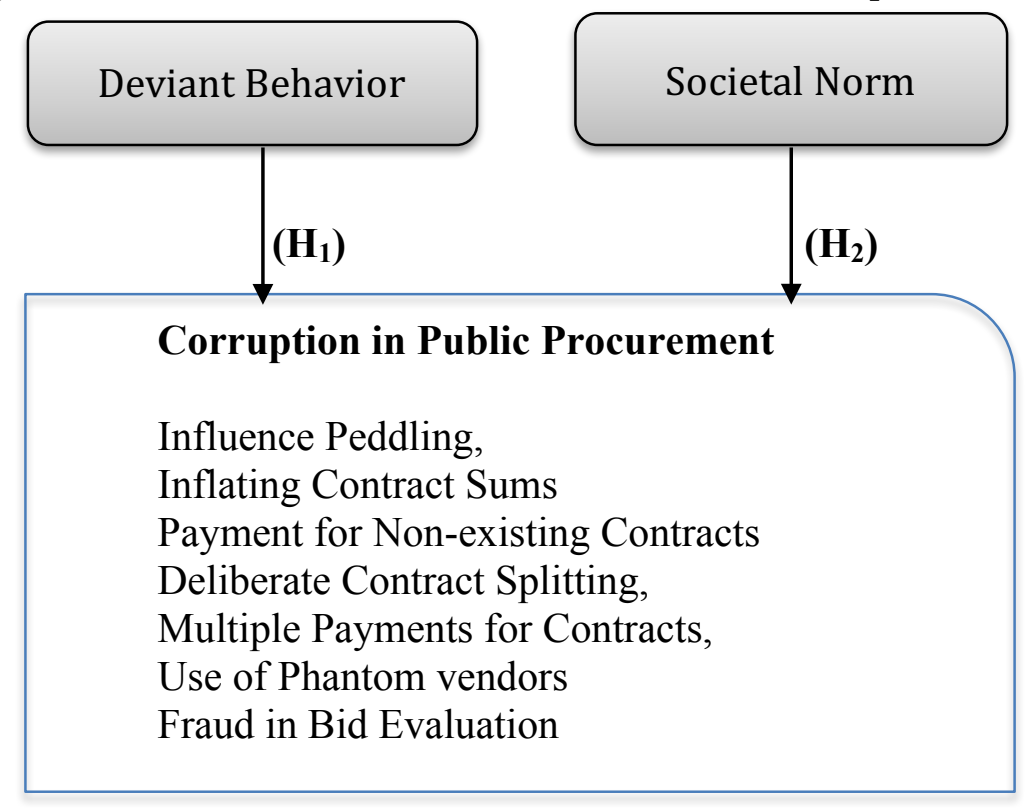

\section{METHOD}

This study employed quantitative design and made use of a hypothesis testing approach to determine the level of responsiveness of public servants to corruption in Ghana. The data collection instruments used was closed-ended questionnaires. The sample for the study included Procurement and Stores Officers and other Principal Officers such as Coordinating Directors, Finance Officers, Budget and Planning Officers, Engineers and Internal Auditors as well as employees selected from 25 MMDAs across the country. A total of 450 questionnaires were administered to respondents working either as principal officers or as employees whose work directly or indirectly relates to procurement. In all, 415 questionnaires were returned and these formed the basis for the analysis and hypothesis testing.

The tool for data analysis used for the study has been structured into two main sections; the first section was used to determine and measure the existence of corruption within the procurement process. While the second section was used to measure the extent to which corruption in public procurement in Ghana is a societal norm and a deviant behavior. Pretesting of questionnaires was done on 10 procurement professionals for purposes of validity and reliability. Cronbach's alpha was used as the main measure of internal consistency reliability. A more appropriate and accepted value for Cronbach's Alpha is 0.70 (Malhotra, 2004). However, the calculated Cronbach's Alpha for the questionnaire as a whole was above 70 percent as presented in table 1. The 81\% Cronbach's Alpha pre-supposes a high internal consistency and reliability among the questions posed to respondents.

\section{Reliability Analysis}

\section{DATA ANALYSIS AND DISCUSSIONS}

The reliability of an instrument refers to its capability to provide a steady and stable measurement. According to Cooper and Schindler (2003) reliability assessments entails the stability, equivalence and internal consistency of an instrument. A well-known reliability coefficient is the Cronbach's alpha, which measures internal dependability by finding out how all items on a test identify with every single other thing and to the aggregate test internal reliability of information. 
Table 1: Reliability Test of Constructs

\begin{tabular}{lccl}
\hline Factors & Cronbach's Alpha & No. of Items & Comments \\
\hline Deviant Behaviour & 0.75 & 12 & Accepted \\
Societal Norms & 0.85 & 12 & Accepted \\
Corruption in Public Procurement & 0.81 & 16 & Accepted \\
\hline
\end{tabular}

\section{Descriptive statistics}

In order to examine the central tendency of the various variables, the study employed the mean statistic. From table 2, it can be observed that the highest mean is in relation to "Use of Phantom Vendors" with a mean value of 4.95 which suggest that majority of respondents agreed to the fact that the use of phantom vendors is the main corrupt practice within public procurement of Ghana. This is closely followed by "Inflating Contract Sums" with a mean score of 4.85. This goes to establish the fact that, inflating of contracts sums for personal gains at the expense of the state is a dominant corrupt practice within public procurement in Ghana. Other forms of corruption identified includes: Payment for Non-existing Contracts, Deliberate Contract Splitting, Multiple Payments for Contracts and Influence Peddling which had mean scores of $4.63,4.55,4.53$ and 4.72 respectively. The least mean score of 3.45 is in relation to Fraudulent Bid Evaluation.

In assessing central tendency, it is also essential to examine how the real values deviate from the mean (standard deviation). The closer they are to zero (0) the better. From the table below (table 2), one can observe that the lowest deviation, in this case the best deviation statistic of 0.85 corresponds to the use of Phantom Vendors while the highest deviation statistic of 1.22 is in relation to Payment for Non-existing Contracts.

Table 2: Mean and Standard deviation

\begin{tabular}{|c|c|c|c|}
\hline Variable & $\mathrm{N}$ & Mean Statistic & Standard Deviation \\
\hline Influence Peddling & 415 & 4.72 & 0.91 \\
\hline Inflating Contract Sums & 415 & 4.85 & 1.18 \\
\hline $\begin{array}{l}\text { Payment for Non-existing } \\
\text { Contracts }\end{array}$ & 415 & 4.63 & 1.22 \\
\hline Deliberate Contract Splitting & 415 & 4.55 & 1.36 \\
\hline $\begin{array}{l}\text { Multiple Payments for } \\
\text { Contracts }\end{array}$ & 415 & 4.53 & 1.38 \\
\hline Use of Phantom vendors & 415 & 4.95 & 0.85 \\
\hline Fraud in Bid Evaluation & 415 & 3.68 & 1.40 \\
\hline
\end{tabular}

The study carried out a coefficient of determination to assess how well the statistical model was likely to forecast future outcomes. The coefficient of determination explains the degree to 
which changes in the dependent variables can be explained by the change in the independent variables. It could also mean the percentage of variation in the dependent variable herein, deviant Behaviour and Societal Norm that is explained by all the seven independent variables (Influence Peddling, Inflating Contract Sums, Payment for Non-existing Contracts, Deliberate Contract Splitting, Multiple Payments for Contracts, Use of Phantom vendors and Fraud in bid Evaluation). Analysis of Variance (ANOVA) and Correlation analysis were applied to test the research hypotheses on whether there is any significant difference between the study variables. Analysis of variance and Correlation is a statistical test generally used to measure and test hypothesis formulated. The study proposed the following hypotheses:

\section{H1: Corruption in Public Procurement is largely a phenomenon of Deviant Behaviour} H2: Corruption in Public Procurement is largely a phenomenon of Societal Norms

\section{Analysis of Variance (ANOVA)}

From the illustrations below, the results of Analysis of Variance (ANOVA) on Corruption within public procurement in Ghana as against Deviant Behaviour and Societal Norm can be observed. The ANOVA results for the regression coefficient indicates a significance of the $\mathrm{F}$ is 0.000 which is less that 0.05 implying that the predictor coefficient is not equal to zero. This also implies a good fit for the model.

Table 3: Analysis of Variance

\begin{tabular}{lccccc}
\hline Model & Sum of Squares & $\boldsymbol{d f}$ & Mean Squares & $\boldsymbol{F}$ & Sig \\
\hline Regression & 46.793 & 9 & 5.199 & 13.522 & .000 \\
Residuals & 24.993 & 65 & .385 & & \\
\hline Total & 71.787 & 74 & & & \\
\hline
\end{tabular}

\section{Coefficient of Correlation}

Table 5 below shows the correlation between independent variables (Influence Peddling, Inflating Contract Sums, Payment for Non-existing Contracts, Deliberate Contract Splitting, Multiple Payments for Contracts, Use of Phantom vendors and Fraudulent Bid Evaluation and dependent variables - Deviant Behaviour and Societal Norm) were positive. Influence Peddling had a correlation of $0.362, \mathrm{p}<0.01$ with Deviant Behaviour and had a correlation of 0.677, $\mathrm{p}<0.01$ with Societal Norm. Inflating Contract Sums also had a correlation of $0.486, \mathrm{p}<0.01$ with Deviant Behaviour, and 0.748, $\mathrm{p}<0.01$. Again, Payment for Non-existing Contracts had a correlation of 0.330, $\mathrm{p}<0.01$ with Deviant Behaviour and had a correlation of 0.588, $\mathrm{p}<0.01$ with Societal Norm. Deliberate Contract Splitting had a correlation of $0.401, \mathrm{p}<0.01$ with Deviant Behaviour and had a correlation of value of $0.623, \mathrm{p}<0.01$ with Societal Norm. Multiple Payments for Contracts had a correlation of 0.207, $\mathrm{p}<0.01$ with Deviant Behaviour and had a correlation of $0.551, \mathrm{p}<0.01$ with Societal Norm. While the Use of Phantom vendors had a correlation of $0.443, \mathrm{p}<0.01$ and $0.666, \mathrm{p}<0.01$ with Deviant Behaviour and Societal Norm respectively. Finally, Fraud in Bid Evaluation had a correlation of $0.386, \mathrm{p}<0.01$ and 0.594 , $\mathrm{p}<0.01$ with Deviant Behaviour and Societal Norm respectively. These results presuppose that there is a positive correlation between all the seven independent variables and Deviant Behaviour and Societal Norm. However, it is worth noting that, the correlation values between all seven independent variables and Societal Norms were higher indicating that Ghanaians perceive corruption as a normal phenomenon. In other words, corruption in Ghana has been accepted by society as the "new normal" rather that an act perpetuated by few miscreants. 
Table 4: Correlation between Independent and dependent Variables

\begin{tabular}{|c|c|c|c|c|c|c|c|c|c|c|}
\hline \\
\hline & & 1 & 2 & 3 & 4 & 5 & 6 & 7 & 8 & 9 \\
\hline \multirow[t]{3}{*}{$\begin{array}{l}\text { Influence } \\
\text { Peddling }\end{array}$} & $\begin{array}{l}\text { Pearson } \\
\text { Correlation }\end{array}$ & 1.000 & & & & & & & & \\
\hline & Sig. (2-tailed) & - & & & & & & & & \\
\hline & $\mathrm{N}$ & 415 & & & & & & & & \\
\hline \multirow{3}{*}{$\begin{array}{l}\text { Inflating } \\
\text { Contract } \\
\text { Sums }\end{array}$} & $\begin{array}{l}\text { Pearson } \\
\text { Correlation }\end{array}$ & $0.396^{*}$ & 1.000 & & & & & & & \\
\hline & Sig. (2-tailed) & 0.002 & - & & & & & & & \\
\hline & $\mathrm{N}$ & 415 & 415 & & & & & & & \\
\hline \multirow{3}{*}{$\begin{array}{l}\text { Payment } \\
\text { for Non- } \\
\text { existing } \\
\text { Contracts }\end{array}$} & $\begin{array}{l}\text { Pearson } \\
\text { Correlation }\end{array}$ & $0.504^{* *}$ & $0.302^{*}$ & 1.000 & & & & & & \\
\hline & $\begin{array}{l}\text { Sig. } \\
\text { (2-tailed) }\end{array}$ & 0.000 & 0.001 & - & & & & & & \\
\hline & $\mathrm{N}$ & 415 & 415 & 415 & & & & & & \\
\hline \multirow{3}{*}{$\begin{array}{l}\text { Deliberat } \\
\text { e Contract } \\
\text { Splitting }\end{array}$} & $\begin{array}{l}\text { Pearson } \\
\text { Correlation }\end{array}$ & 0.351 & $0.242^{*}$ & $0.39 *$ & 1.000 & & & & & \\
\hline & $\begin{array}{l}\text { Sig. } \\
\text { (2-tailed) }\end{array}$ & 0.000 & 0.025 & 0.000 & - & & & & & \\
\hline & $\mathrm{N}$ & 415 & 415 & 415 & 415 & & & & & \\
\hline \multirow{3}{*}{$\begin{array}{l}\text { Multiple } \\
\text { Payments } \\
\text { for } \\
\text { Contracts }\end{array}$} & $\begin{array}{l}\text { Pearson } \\
\text { Correlation }\end{array}$ & 0.437 & $0.337^{*}$ & 0.466 & $0.689^{*}$ & 1.000 & & & & \\
\hline & $\begin{array}{l}\text { Sig. } \\
\text { (2-tailed) }\end{array}$ & 0.000 & 0.030 & 0.000 & 0.000 & - & & & & \\
\hline & $\mathrm{N}$ & 415 & 415 & 415 & 415 & 415 & & & & \\
\hline \multirow{3}{*}{$\begin{array}{l}\text { Use of } \\
\text { Phantom } \\
\text { vendors }\end{array}$} & $\begin{array}{l}\text { Pearson } \\
\text { Correlation }\end{array}$ & 0.422 & .425 & 0.420 & 0.533 & $0.654^{* *}$ & 1.000 & & & \\
\hline & $\begin{array}{l}\text { Sig. } \\
\text { (2-tailed) }\end{array}$ & 0.000 & 0.049 & 0.000 & 0.000 & 0.000 & - & & & \\
\hline & $\mathrm{N}$ & 415 & 415 & 415 & 415 & 415 & 415 & & & \\
\hline \multirow[t]{3}{*}{$\begin{array}{l}\text { Fraud in } \\
\text { Bid } \\
\text { Evaluation }\end{array}$} & $\begin{array}{l}\text { Pearson } \\
\text { Correlation }\end{array}$ & $0.440^{*}$ & $0.423^{*}$ & 0.392 & $0.667^{* *}$ & $0.658^{* *}$ & $0.532^{* *}$ & 1.000 & & \\
\hline & $\begin{array}{l}\text { Sig. } \\
\text { tailed) }\end{array}$ & 0.000 & 0.000 & 0.000 & 0.000 & 0.000 & 0.000 & - & & \\
\hline & $\mathrm{N}$ & 415 & 415 & 415 & 415 & 415 & 415 & 415 & & \\
\hline Deviant & Pearson & 0.362 & & & & & & & & \\
\hline
\end{tabular}


Dza, M., Kyeremeh, E., Dzandu, S. S. K., \& Affran, S. (2018). Corruption in Public Procurement in Ghana: societal norm or deviant behaviour? Archives of Business Research, 6(12), 56-66.

\begin{tabular}{|l|l|l|l|l|l|l|l|l|l|l|}
\hline Behaviour & Correlation & & $0.486^{* *}$ & 0.330 & $0.401^{*}$ & $0.207^{*}$ & $0.443^{* *}$ & 0.386 & 1.000 & \\
\cline { 2 - 11 } & Sig. (2-tailed) & 0.00 & 0.000 & 0.000 & 0.000 & 0.000 & 0.000 & 0.000 & - & \\
\cline { 2 - 11 } & $\mathrm{N}$ & 415 & 415 & 415 & 415 & 415 & 415 & 415 & 415 & \\
\hline $\begin{array}{l}\text { Societal } \\
\text { Norm }\end{array}$ & $\begin{array}{l}\text { Pearson } \\
\text { Correlation }\end{array}$ & $0.677^{*}$ & $0.748^{*}$ & 0.588 & $0.623^{*}$ & 0.551 & 0.666 & $0.678^{*}$ & 0.594 & 1.000 \\
\cline { 2 - 11 } & \begin{tabular}{l} 
Sig. (2-tailed) \\
\cline { 2 - 10 }
\end{tabular} & 0.000 & 0.000 & 0.000 & 0.000 & 0.000 & 0.000 & 0.000 & 0.000 & - \\
\hline
\end{tabular}

\section{Multiple Correlation}

The seven independent variables that were studied - Influence Peddling, Inflating Contract Sums, Payment for Non-existing Contracts, Deliberate Contract Splitting, Multiple Payments for Contracts, Use of Phantom vendors and Fraud in Bid Evaluation, explain only 66.3\% of corruption in public procurement as a deviant Behavior as represented by the $\mathrm{R}$ square. This pre-supposes that all the seven independent variables studied in this paper, suggest that $66.3 \%$ of corruption within public procurement occur as a result of deviant behavior. While other factors not studied in this paper account for corruption within public procurement in Ghana.

Table 5: Multiple Correlation Coefficient Model Summary

\begin{tabular}{ccccc}
\hline Model & $\mathrm{R}$ & $\mathrm{R}-$ Square & $\begin{array}{c}\text { Adjusted } \\
\mathrm{R}-\text { Square }\end{array}$ & $\begin{array}{c}\text { Standard Error of } \\
\text { the Estimate }\end{array}$ \\
\hline 1 & .814 & .663 & .369 & .213
\end{tabular}

a. Predictors: (Constant), Influence Peddling, Inflating Contract Sums, Payment for Nonexisting Contracts, Deliberate Contract Splitting, Multiple Payments for Contracts, Use of Phantom vendors and Fraud in Bid Evaluation. R denotes multiple regression coefficient; R Square denotes coefficient of determination.

Table 6 Summary Results of Hypothesis Testing

Hypothesis Descriptions Results

\begin{tabular}{lll}
\hline H1 & $\begin{array}{l}\text { Corruption in Public Procurement is largely a } \\
\text { phenomenon of Deviant Behavior }\end{array}$ & Accepted \\
\hline H2 & $\begin{array}{l}\text { Corruption in Public Procurement is largely a } \\
\text { phenomenon of Societal Norms }\end{array}$ & Accepted \\
\hline
\end{tabular}

\section{RESULTS}

The results obtained from this study revealed the following outcomes; The descriptive analysis conducted, confirms the position of literature that the public service of Ghana is fraught with procurement related corruption. Again the correlation analysis shows that corruption in Ghana has become a societal norm rather than deviant behaviour. The first hypothesis (H1: Corruption in Public Procurement is largely a phenomenon of Deviant Behaviour) found a 
positive relationship between Influence Peddling, Inflating Contract Sums, Payment for Nonexisting Contracts, Deliberate Contract Splitting, Multiple Payments for Contracts, Use of Phantom vendors and Fraud in Bid Evaluation and Deviant Behaviour but the result was not significant enough. While the study found hypothesis two (H2: Corruption in Public Procurement is largely a phenomenon of Societal Norms) which assessed the relationship between the same seven independent variables to be significantly related to Societal Norm. The above results reveal that corruption within public procurement in Ghana has grown beyond being a mere deviant behaviour into an acceptable societal norm.

\section{CONCLUSION}

The paper examined procurement related corruption in the public service of Ghana. The objective (formulated into dependent variable) is to find out whether the incidence of corruption in Ghana can be likened to deviant behaviour or be equated to acceptable societal behaviour. The objective is tied to seven independent variables - Influence Peddling, Inflating Contract Sums, Payment for Non-existing Contracts, Deliberate Contract Splitting, Multiple Payments for Contracts, Use of Phantom vendors and Fraud in Bid Evaluation. It was evident that corruption in most cases begins as deviant behaviour but with time society tends to accept deviant behaviours as norms. This assertion is supported by Csapodi et; al., (2011) who opined that persistent corrupt behaviour often develops into a social norm as society becomes used to the practice and hence accepts deviant behaviour as the new way of doing things. The study found that the deliberate use of fictitious vendors and multiple payments for contracts are significantly used by public servants to defraud the country. Other serious forms of procurement related breaches identified are: officials paying their cronies for contracts that do not exist; multiple payments for contracts among others. Evidence from this study ostensibly shows how procurement related corruption is engrained in the mindset and fibre of most Ghanaians to the extent that the phenomenon is no longer seen as a serious cancer that must be seriously dealt with. Indeed the acceptance of corruption as a normal societal practice will make the fight against corruption extremely difficult as witnesses to corrupt practices are reluctant to expose perpetrators of the act to appropriate authorities, as they see nothing wrong with being corrupt.

\section{References}

Auditor-General's Report (2016) on the Public Accounts of Ghana - Ministries, Departments and Other Agencies (MDAs)

Baez Camargo, C., \& Passas, N. (2017). Hidden agendas, social norms and why we need to re-think anti-corruption. [Online] Available at: https://www. oecd.org/cleangovbiz. In Integrity-Forum-2017-Baez\% 20Camargo-Passashidden-agendas-social-norms. pdf [Accessed 2809 2017].

Bartle, R. J., \& Korosec, L. R. (2003). A review of state procurement and contracting Journal of Public Procurement, 3(2), 192-214

Blackburn, K., \& Forgues-Puccio, G. F. (2009). Why is corruption less harmful in some countries than in others? Journal of Economic Behavior \& Organization, 72(3), 797-810

Cooper, D.R. and Schindler, P.S. (2003), Business Research Methods, 8th ed., McGraw-Hill/Irwin, New York, NY.

Csapodi, P., Takács, I., \& György-Takács, K. (2011). Corruption as a Deviant Social Attitude Public Finance Quarterly, 56(1), 27

European Commission (2014a) A new EU Framework to strengthen the Rule of Law, Communication, COM (2014) 158 Final, 11 March 2014

Hoffmann, L. K., \& Patel, R. N. (2017). Collective action on corruption in Nigeria: A social norms approach to connecting society and institutions. London: Chatham House.

Khramkin, A. (2007), "Anti-corruption practices in public procurement”, discussion paper submitted to the Government Procurement Institute of the Russian Civil Service Academy 
Malhotra, N. K. (2004). Marketing Research: An applied orientation. $4^{\text {th }}$ ed. New Jersey: Prentice Hall.

Mishra, A. (2005). The economics of corruption Oxford University Press

OECD, (2007) Bribery in Public Procurement: Methods, Actors and Counter-Measures, Centre for Democratic Development (CDD-Ghana), Vol. 4 No. 2, pp. 1-6.

Pertiwi, K. (2018). Contextualizing Corruption: A Cross-Disciplinary Approach to Studying Corruption in Organizations. Administrative Sciences, 8(2), 12

Public Procurement Act, 2003 (Act 663) of the Republic of Ghana

Public Procurement Manual, (2003) of the Republic of Ghana

Stansbury, N. (2005) Exposing the foundations of corruption in construction. Global Corruption Report, 2005, 3655

United Nations Convention against Corruption (UNCAC) (2013) Good Practices in Ensuring Compliance with Article 9 of the United Nations Convention against Corruption

Ware, G. T., Moss, S., Edgardo, J. C. \& Noone G. P. (2007) Corruption in Public Procurement: A Perennial Challenge, In Edgardo, J. Campos \& Sanjay Pradhan (eds) The Many Faces of Corruption: Tracking Vulnerabilities at Sector Level World Bank: Washington D.C 